\title{
Analisis Kesalahan Siswa Dalam Menyelesaikan Soal Pada Materi Operasi Penjumlahan dan Pengurangan Bentuk Aljabar Bagi Siswa Kelas VII SMP Kristen 2 Salatiga
}

\author{
Cindy Aditya Cahyani ${ }^{1}$, Sutriyono ${ }^{2}$ \\ Pendidikan Matematika, Universitas Kristen Satya Wacana, 202014104@student.uksw.edu
}

\begin{abstract}
INFO ARTIKEL
Riwayat Artikel:

Diterima: 03-03-2018

Disetujui: 22-03-2018

\section{Kata Kunci:}

Kesalahan

Operasi

Aljabar

ABSTRAK

Abstrak: Penelitian ini bertujuan untuk mengetahui jenis-jenis kesalahan yank dilakukan siswa kelas VII SMP Kristen 2 Salatiga dalam mengerjakan soal pada mater: operasi penjumlahan dan pengurangan bentuk aljabar, serta untuk mengetahui faktor faktor penyebab siswa melakukan kesalahan. Metode penelitian ini adalah deskripti: kualitatif dengan menganalisis kesalahan siswa dari instrumen yang diberikan. Sampe yang diambil adalah siswa kelas VII B SMP Kristen 2 Salatiga dengan jumlah subjek yaitu 4 siswa. Hasil penelitian ini menunjukkan bahwa terdapat 3 jenis kesalahan yanধ dilakukan, yaitu kesalahan konsep, kesalahan operasi, dan kesalahan ceroboh. Faktor faktor penyebab siswa melakukan kesalahan yaitu kurang teliti dan belum menguasa: materi.
\end{abstract}

\begin{abstract}
This study aims to find out the types of mistakes made by seventh graders of SMP Kristen 2 Salatiga in working on the matter of addition and algebraic algebraism and to know the factors causing students to make mistakes. The research method is descriptive qualitative by analyzing student error from the given instrument. Samples taken are students of class VII B Christian SMP 2 Salatiga with the number of subjects that is 4 students. The results of this study indicate that there are 3 types of mistakes made, namely concept errors, operating errors, and careless errors. Factors causing students to make mistakes are less thorough and have not mastered the material.
\end{abstract}

\section{A. LATAR BELAKANG}

Pendidikan matematika atau belajar matematika dapat membentuk pola berpikir secara ilmiah. Helly (2014) mengatakan bahwa matematika dapat melatih seseorang untuk berpikir secara sederhana. Matematika perlu diberikan kepada semua peserta didik mulai dari sekolah dasar sampai pada tingkat perguruan tinggi, termasuk juga pada tingkat Sekolah Menengah Pertama (SMP), untuk membekali peserta didik supaya mampu berpikir logis, analitis, sistematis, kritis, dan kreatif, serta memiliki kemampuan bekerjasama (Depdiknas, 2006).

Matematika merupakan sebuah ilmu dasar untuk membantu memahami ilmu pengetahuan yang lain (Rahmat,2013). Matematika merupakan ilmu yang penting untuk ilmu lainnya, seperti yang diungkapkan oleh Wahyudin (2002) yang menyatakan bahwa matematika merupakan cabang utama ilmu dari ilmu filsafat yang menjadi ibu dari segala ilmu, oleh karena itu matematika merupakan ilmu pokok yang diajarkan kepada seluruh siswa di setiap jenjang pendidikan.
Matematika memiliki keterkaitan dan menjadi pendukung berbagai bidang ilmu serta berbagai aspek kehidupan manusia. Hal ini menunjukkan pentingnya pelajaran matematika diberikan kepada siswa. Tetapi di sisi lain, matematika juga dianggap sebagai mata pelajaran yang cukup sulit dibandingkan mata pelajaran lainnya, bahkan cukup menakutkan bagi siswa. Pernyataan tersebut juga diungkapkan oleh Nawangsari (2007) bahwa matematika sejak dulu memang dianggap oleh siswa sebagai pelajaran yang sulit dan menakutkan. Karakteristik matematika yang abstrak dan sistematis menjadi salah satu alasan sulitnya siswa mempelajari matematika.

Menurut Supatmono (2009), kesulitan siswa dalam mempelajari matematika dikarenakan siswa tidak membangun sendiri tentang pengetahuan konsep-konsep matematika tanpa mengetahui makna yang terkandung pada konsep tersebut sehingga pada saat siswa menyelesaikan masalah matematika siswa sering melakukan kesalahan dan tidak menemukan solusi penyelesaian masalahnya. Pentingnya memahami konsep merupakan dasar untuk belajar matematika. Materi matematika SMP 
terdiri dari banyak sub materi. Salah satunya adalah sub materi operasi penjumlahan dan pengurangan bentuk aljabar dalam materi aljabar yang dipelajari di kelas VII SMP semester I. Materi tersebut adalah salah satu bagian dari pembelajaran matematika yang membutuhkan pemahaman dasar atau pemahaman konsep yang diperlukan siswa sehingga nantinya prestasi siswa secara keseluruhan dalam pembelajaran matematika meningkat. Penguasaan materi yang baik pada siswa dapat ditinjau dari hasil yang benar pada penyelesaian soal. Dari hasil-hasil soal yang dikerjakan oleh siswa di sekolah banyak dilihat kesalahan dalam menyelesaikan soal operasi penjumlahan dan pengurangan bentuk aljabar.

Berdasarkan pengalaman peneliti ketika mengajarkan Operasi Penjumlahan dan Pengurangan Bentuk Aljabar di kelas VII SMP Kristen 2 Salatiga, peneliti menemukan banyak kesalahan siswa saat menyelesaikan soal-soal tentang sub materi Operasi Penjumlahan dan Pengurangan Bentuk Aljabar. Setelah diidentifikasi siswa belum menguasai konsep bentuk aljabar. Siswa belum terampil dalam operasi hitung bilangan bulat. Hal ini dikarenakan siswa kurang berlatih dalam mengerjakan soal-soal. Selain itu, siswa masih belum memahami definisi dari variabel, koefisien, serta konstanta. Letak kesalahan siswa dapat diketahui dengan diberikannya tes. Pentingnya adanya analisis kesalahan siswa untuk mengetahui letak kesalahan yang dilakukan siswa saat mengerjakan soal.

Kesalahan adalah kekeliruan; perbuatan yang salah (melanggar hukum dan sebagainya) (Depdikbud, 1999:855). Menurut Soedjadi (2000:13), kesalahan itu dihubungkan dengan objek dasar matematika, kesalahan yang dimaksud yaitu: 1) Kesalahan fakta adalah kekeliruan dalam menuliskan konvensi-konvensi yang dinyatakan dengan simbolsimbol matematika. Contoh: kesalahan dalam mengubah permasalahan ke dalam bentuk model matematika, kesalahan dalam menginterpretasikan hasil yang didapatkan dan kesalahan dalam menuliskan simbol-simbol matematika. 2) Kesalahan konsep adalah kekeliruan dalam menggolongkan atau mengklasifikasikan sekumpulan objek. Konsep yang dimaksud dalam matematika dapat berupa definisi. Contoh: kesalahan dalam menggolongkan suatu relasi, apakah merupakan suatu fungsi atau tidak. 3) Kesalahan operasi adalah kekeliruan dalam pengerjaan hitung, pengerjaan aljabar, dan pengerjaan matematika yang lain. Contoh: kesalahan dalam menjumlahkan, mengurangkan, dan kesalahan dalam operasi matematika lainnya. 4) Kesalahan prinsip adalah kekeliruan dalam mengaitkan beberapa fakta atau beberapa konsep. Contoh: kesalahan dalam menggunakan rumus ataupun teorema serta kesalahan dalam menggunakan prinsip-prinsip sebelumnya.
Adapun kesalahan-kesalahan

dalam menyelesaikan soal matematika, yaitu: (a) Kesalahan dalam memahami soal, yang terjadi jika siswa salah dalam menemukan hal yang diketahui, ditanyakan dan tidak dapat menuliskan apa yang dikehendaki; (b) Kesalahan dalam menggunakan rumus, yang terjadi jika siswa tidak mampu mengidentifikasi rumus atau metode apa yang akan digunakan atau diperlukan dalam menyelesaikan soal; (c) Kesalahan dalam operasi penyelesaiannya, yang terjadi jika siswa salah dalam melakukan perhitungan ataupun; (d) Kesalahan dalam menyimpulkan, yang terjadi jika siswa tidak memperhatikan kembali apa yang ditanyakan dari soal dan tidak membuat kesimpulan dari hasil perhitungannya, karena siswa beranggapan bahwa hasil perhitungannya merupakan penyelesaian dari permasalahan yang ada.

Menurut uraian di atas, maka letak kesalahan pada penelitian ini dikategorikan sebagai berikut: (a) Kesalahan dalam penerapan konsep, siswa dikatakan melakukan kesalahan konsep apabila siswa tidak mengerti definisi suatu istilah dalam matematika atau siswa belum menguasai sub materi dasar yang diberikan pada pembahasan salah satu materi. Contohnya: belum mengerti definisi variabel, koefisien, dan konstanta untuk dasar materi aljabar. (b) Kesalahan dalam operasi penyelesaiannya, siswa dikatakan melakukan kesalahan dalam operasi penyelesaiannya apabila siswa telah mampu mentransformasikan soal akan tetapi tidak mengetahui prosedur yang dibutuhkan untuk mengerjakan operasi atau metode secara benar dan akurat dan (c) Kesalahan ceroboh, siswa dikatakan melakukan kesalahan dalam menyelesaikan soal matematika dikarenakan siswa lupa konsep, rumus ataupun operasi yang akan digunakannya untuk menyelesaikan soal matematika.

Hal ini sesuai dengan penelitian yang dilakukan Natalia (2016) yang menghasilkan faktor-faktor penyebab siswa melakukan kesalahan diantaranya kurang teliti dalam melakukan operasi hitung, belum menguasai materi, tidak mengerti maksud dari soal yang diberikan, kurang berlatih dalam menyelesaikan soal -soal tentang operasi bentuk aljabar, dan suasana kelas yang kurang kondusif.

Untuk mengetahui faktor penyebab kesalahan siswa dalam menyelesaikan soal dapat diketahui dari kesalahan yang dibuatnya. Faktor penyebab kesalahan dapat dilihat dari faktor penyebab kesulitan belajar siswa. Hubungan antara kesalahan dengan kesulitan sangat erat dan saling mempengaruhi satu sama lain. Kesalahan dan kesulitan merupakan dua hal yang berbeda dan sangat erat kaitannya, bahkan sulit untuk menentukan apakah kesulitan yang menyebabkan kesalahan atau kesalahan yang menyebabkan kesulitan. 
Menurut Haji dalam Syafi'atur Rohmah (2012:25), faktor-faktor yang menyebabkan siswa mengalami kesulitan belajar sehingga menyebabkan siswa tersebut melakukan kesalahan dalam menyelesaikan soal-soal ada dua segi, yaitu segi kognitif dan segi non kognitif. Segi kognitif meliputi hal-hal yang berhubungan dengan kemampuan intelektual siswa dan cara siswa memproses atau mencerna materi matematika dalam pikirannya. Sedangkan segi bukan kognitif adalah semua faktor di luar hal-hal yang berhubungan dengan kemampuan intelektual seperti sikap, kepribadian, cara belajar, kesehatan jasmani, keadaan emosional, cara mengajar guru, fasilitas-fasilitas belajar, serta suasana rumah.

Dari penjelasan di atas, dapat diketahui beberapa faktor penyebab siswa mengalami kesalahan, yaitu berasal dari faktor kognitif dan non kognitif siswa. Faktor kognitif meliputi kemampuan intelektual siswa dalam menyelesaikan soal matematika yang diberikan. Sedangkan faktor non kognitif adalah cara belajar siswa dimana cara belajar siswa dapat dipengaruhi oleh kesiapan, kedisiplinan waktu belajar dan sikap siswa terhadap matematika. Dalam penelitian ini, faktor-faktor penyebab siswa melakukan kesalahan dalam setiap letak kesalahan yang dilakukan yang menyangkut faktor kognitif dan non kognitif digali sejelas mungkin melalui wawancara.

Oleh karena itu, penelitian ini bertujuan untuk menganalisis kesalahan dalam menyelesaikan soal pada materi operasi penjumlahan dan pengurangan bentuk aljabar bagi siswa kelas VII SMP KRISTEN 2 SALATIGA.

\section{B. METODE PENELITIAN}

Jenis penelitian yang digunakan dalam penelitian ini adalah penelitian deskriptif kualitatif. Penelitian ini dilakukan di SMP Kristen 2 Salatiga dengan pengambilan subjek berdasarkan purposive sampling sebanyak 4 siswa dari kelas VII B. Pengambilan data dilakukan pada bulan Oktober-November. Metode pengumpulan data dalam penelitian ini dengan menggunakan tes tertulis dan wawancara. Instrumen yang digunakan dalam penelitian ini berupa tes uraian yang berisi tentang soal-soal yang berkaitan dengan operasi penjumlahan dan pengurangan bentuk aljabar. Tes yang dilakukan dengan $1 \mathrm{x}$ pertemuan ( 2 jam pelajaran) pada tanggal 22 November 2017. Instrumen wawancara dalam penelitian ini menggunakan pedoman wawancara semi terstruktur.

\section{HASIL DAN PEMBAHASAN}

Dilakukan tes pada tanggal 22 November $2017 \mathrm{di}$ Kelas VII B SMP Kristen 2 Salatiga. Berdasarkan penelitian yang dilakukan menghasilkan analisis hasil pekerjaan siswa sebagai berikut:

\section{Analisis Data Hasil Pekerjaan Siswa}

TABEL 1

JENIS KESALAHAN DAN TIPE KESALAHAN SISWA KELAS VII B

\begin{tabular}{|c|c|c|c|}
\hline $\begin{array}{c}\text { Jenis } \\
\text { Kesalahan }\end{array}$ & $\begin{array}{c}\text { No } \\
\text { Soal } \\
\end{array}$ & $\begin{array}{c}\text { Tipe } \\
\text { Kesalahan }\end{array}$ & No. Presensi \\
\hline \multirow{4}{*}{$\begin{array}{c}\text { Kesalahan } \\
\text { Konsep }\end{array}$} & 1 & $\begin{array}{c}\text { Tidak dapat } \\
\text { Menentukan } \\
\text { Variabel } \\
\end{array}$ & $\begin{array}{c}4,6,8,18,23,25 \\
26 .\end{array}$ \\
\hline & 2 & $\begin{array}{c}\text { Tidak dapat } \\
\text { Menentukan } \\
\text { Koefisien } \\
\end{array}$ & $\begin{array}{c}2,3,4,6,7,8,16 \\
17,18,19,21,23 \\
24,25,26 .\end{array}$ \\
\hline & 3 & $\begin{array}{l}\text { Tidak dapat } \\
\text { Menentukan } \\
\text { Banyak suku }\end{array}$ & $\begin{array}{c}2,3,4,5,6,8,11, \\
12,13,15,16,17 \\
18,19,22,23,25, \\
26 .\end{array}$ \\
\hline & 4 & $\begin{array}{c}\text { Tidak dapat } \\
\text { Menentukan } \\
\text { Suku Sejenis }\end{array}$ & $\begin{array}{r}1,2,3,4,5,7,8 \\
12,16,17,18,19 \\
22,23,24,25,26 .\end{array}$ \\
\hline \multirow{2}{*}{$\begin{array}{c}\text { Kesalahan } \\
\text { Operasi }\end{array}$} & 5 & $\begin{array}{l}\text { Perhitungan } \\
\text { Operasi } \\
\text { Penjumlahan } \\
\end{array}$ & $\begin{array}{c}2,16,18,19,23 \\
26 .\end{array}$ \\
\hline & 6 & $\begin{array}{l}\text { Perhitungan } \\
\text { Operasi } \\
\text { Pengurangan }\end{array}$ & $\begin{array}{c}1,2,3,4,5,6,7,8, \\
12,13,16,17,18, \\
19,21,22,23,25, \\
26 .\end{array}$ \\
\hline
\end{tabular}

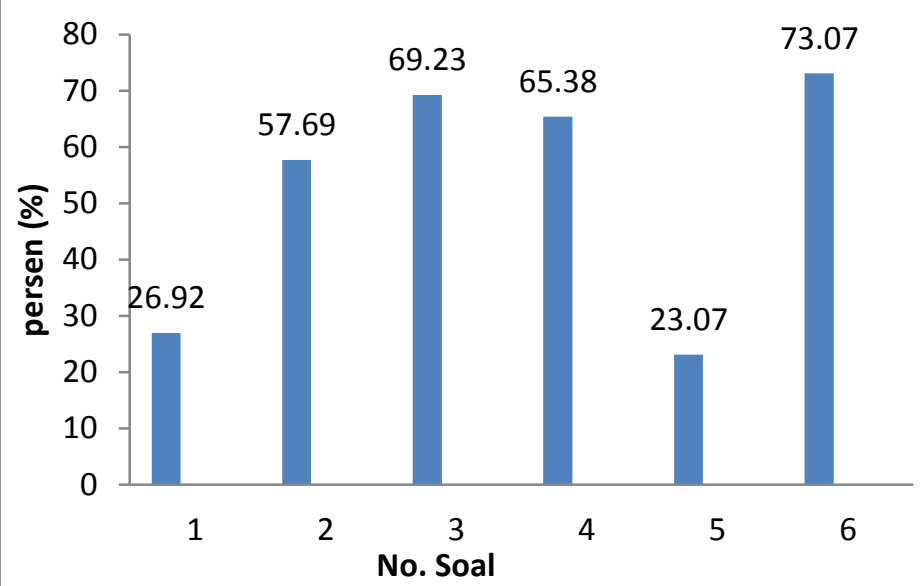

Gambar 1. Persentse Kesalahan Hasil Pekerjaan Siswa

\section{Jenis Kesalahan}

Pada penelitian ini terdapat beberapa kesalahan yang dilakukan siswa yang terlihat pada hasil pekerjaan siswa. Selanjutnya, dilakukan wawancara terhadap 4 subjek yang sesuai dengan penelitian ini. Beberapa kesalahan dan pembahasannya dapat dilihat dibawah ini.

a. Kesalahan Konsep

TABEL 2

TIPE KESALAHAN KONSEP SISWA

\begin{tabular}{cccc}
\hline $\begin{array}{c}\text { No. } \\
\text { Soal }\end{array}$ & Subjek & Jawaban Siswa & $\begin{array}{c}\text { Tipe } \\
\text { Kesalahan }\end{array}$ \\
\hline 1. & Siswa J & a. $v$ & Kesalahan \\
& & b. $v y$ & dalam
\end{tabular}




\begin{tabular}{|c|c|c|c|}
\hline & & & $\begin{array}{c}\text { Menentukan } \\
\text { Variabel }\end{array}$ \\
\hline 2. & $\begin{array}{l}\text { Siswa } \\
\text { M }\end{array}$ & $\begin{array}{l}\text { a. } 3 m-5=3,5 \\
\text { b. } 4 m^{2}-6 m+8=4,6,8\end{array}$ & $\begin{array}{c}\text { Kesalahan } \\
\text { dalam } \\
\text { Menentukan } \\
\text { Koefisien }\end{array}$ \\
\hline 3. & Siswa A & (3) $\begin{array}{l}a, 3,2 \\
b \\
b, 2,4, f_{3}\end{array}$ & $\begin{array}{c}\text { Kesalahan } \\
\text { dalam } \\
\text { Menentukan } \\
\text { Banyak Suku }\end{array}$ \\
\hline 4. & Siswa A & (4) $\begin{array}{ll}a & 4 \\
b & 2\end{array}$ & $\begin{array}{c}\text { Kesalahan } \\
\text { dalam } \\
\text { Menentukan } \\
\text { Suku Sejenis }\end{array}$ \\
\hline
\end{tabular}

Dari hasil wawancara dengan beberapa subjek diatas, subjek 'J' telah mengerti maksut dari suatu variabel. Namun masih belum mampu menyampaikan secara tepat dan benar. Subjek 'M' masih belum mengerti definisi koefisien, yang dia tahu koefisien adalah hanya menyebutkan angka dari suatu bentuk aljabar. Sedangkan subjek 'A' tidak bisa menentukan banyaknya suku karena subjek ' $A$ ' belum mengerti apa itu suku, menurut subjek ' $A$ ' suku adalah angka dalam suatu bentuk aljabar dan subjek ' $A$ ' belum mengerti definisi suku sejenis. Subjek 'a' beranggapan bahwa suku sejenis adalah angka yang sama pada suatu bentuk aljabar.

Oleh karena itu, dapat disimpulkan bahwa ketiga subjek 'J', ' $M$ ', dan ' $A$ ' memiliki kesalahan pada bagian penerapan konsep. Ketiga subjek tersebut belum menguasai konsep pada materi bentuk aljabar.

\section{b. Kesalahan Operasi}

TABEL 3

TIPE KESALAHAN OPERASI

\begin{tabular}{|c|c|c|c|}
\hline $\begin{array}{l}\text { No. } \\
\text { Soal }\end{array}$ & Subjek & Jawaban Siswa & $\begin{array}{c}\text { Tipe } \\
\text { Kesalahan }\end{array}$ \\
\hline 5. & $\begin{array}{c}\text { Siswa } \\
\text { J }\end{array}$ & $\begin{array}{l}\text { a. } 11 x y \\
b \cdot 11 x y \\
c \cdot-14 z\end{array}$ & $\begin{array}{l}\text { Kesalahan } \\
\text { dalam } \\
\text { Perhitungan } \\
\text { Operasi } \\
\text { Penjumlahan }\end{array}$ \\
\hline 6. & $\begin{array}{l}\text { Siswa } \\
\text { B }\end{array}$ & 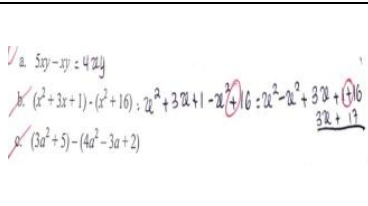 & $\begin{array}{l}\text { Kesalahan } \\
\text { dalam } \\
\text { Perhitungan } \\
\text { Operasi } \\
\text { Pengurangan }\end{array}$ \\
\hline
\end{tabular}

Berdasarkan hasil wawancara yang dilakukan oleh kedua subjek 'J' dan 'B'. Disimpulkan bahwa subjek 'J' tidak mengerti variabel dan suku sejenis. Sehingga pada operasi penjumlahan siswa 'J' beranggapan dengan menjumlahkan semua suku. Sedangkan, subjek 'B' sebenarnya memahami operasi pengurangan yang terdapat pada soal. Namun siswa melakukan kesalahan dengan kurang teliti. Siswa menyadari bahwa siswa salah dalam proses menghitung dan siswa dapat memperbaiki jawabannya hingga tepat.

\section{c. Kesalahan Ceroboh}

Berdasarkan pengelompokkan jenis kesalahan pada konsep dan operasi, terdapat 3 subjek yang termasuk kesalahan konsep dan 2 subjek yang termasuk pada kesalahan operasi. Serta terdapat 1 subjek yang termasuk pada jenis kesalahan ceroboh yaitu siswa 'J'. Dikatakan ceroboh karena siswa mengalami kesalahan pada konsep dan operasi.

\section{SIMPULAN DAN SARAN}

Jenis-jenis kesalahan yang dilakukan oleh siswa kelas VII B SMP Kristen 2 Salatiga dalam mengerjakan soal-soal tentang operasi penjumlahan dan pengurangan bentuk aljabar dikelompokkan menjadi 3 jenis kesalahan dan beberapa tipe kesalahan pada setiap jenis kesalahannya. Berikut ini jenis kesalahan dan tipe kesalahan yang ditemukan dalam penelitian: A) Kesalahan Konsep. Ditemukan beberapa tipe kesalahan konsep, yaitu: 1) kesalahan dalam menentukan variabel. 2) kesalahan dalam menentukan koefisien. 3) kesalahan dalam menentukan banyak suku. 4) kesalahan dalam menentukan suku sejenis. Dari hasil pembahasan di atas, subjek yang melakukan kesalahan pada konsep adalah subjek 'J', 'M', dan 'A'. B) Kesalahan Operasi. Ditemukan beberapa tipe kesalahan Operasi, yaitu: 1) kesalahan dalam perhitungan operasi penjumlahan. 2) kesalahan dalam perhitungan operasi pengurangan. Dari hasil pembahasan di atas, subjek yang melakukan kesalahan pada operasi adalah subjek ' $\mathrm{J}$ ' dan 'B'. C) Kesalahan Ceroboh. Siswa dikatakan ceroboh apabila siswa mengalami kesalahan pada konsep dan kesalahan pada operasi. Jika siswa hanya melakukan salah satu jenis kesalahan, misalnya salah pada konsep tetapi operasi benar atau pada konsep benar tetapi operasi salah, maka siswa tidak dapat dikatakan ceroboh atau melakukan kesalahan ceroboh. Dari hasil pembahasan di atas, subjek yang melakukan kesalahan ceroboh adalah subjek ' J'. Karena subjek 'J' melakukan kesalahan pada konsep dan melakukan kesalahan pada operasi sehingga subjek 'J' dapat dikatakan ceroboh atau masuk dalam jenis kesalahan ceroboh.

Pada hasil analisis tertulis dan wawancara dapat disimpulkan faktor-faktor penyebab siswa melakukan kesalahan, yaitu: 1) siswa belum menguasai materi. 2) siswa masih belum memahami konsep dasar pada materi operasi bentuk aljabar. 3) suasana kelas yang kurang kondusif sehingga siswa sulit dalam memahami materi operasi bentuk aljabar. 4) siswa lupa dengan materi yang diajarkan sehingga tidak dapat mengerjakan soal yang diberikan. 5) 
siswa tidak mengerti maksud soal yang diberikan. 6) siswa kurang teliti dalam melakukan operasi hitung.

Pada penelitian ini peneliti memberikan saran bagi peneliti lain yang sedang melakukan penelitian sejenis dengan menggunakan sub materi selain operasi penjumlahan dan pengurangan bentuk aljabar atau untuk materi yang lain dan penelitian ini dapat menjadikan salah satu penelitian pendukung bagi peneliti lain. Serta, bagi guru agar penelitian ini bermanfaat untuk mengetahui dimana letak kesalahan siswa dalam mengerjakan soal operasi penjumlahan dan pengurangan bentuk aljabar.

\section{UCAPAN TERIMAKASIH}

Penulis mengucapkan terimakasih kepada Prof. Dr. Sutriyono, M.Sc., Ph.D. selaku pembimbing yang senantiasa memberikan bimbingan, nasehat, dan motivasi kepada penulis. Serta untuk kedua orang tua penulis yang selalu memberikan semangat sehingga penelitian ini dapat terselesaikan dengan baik.

\section{REFERENSI}

[1]. Depdikbud. (1999). Evaluasi Belajar. Jakarta: Dirjen Dikdasmen

[2]. Depdiknas. (2006). Kurikulum Tingkat Satuan Pendidikan Jakarta: Depdiknas

[3]. Helly Apriyanti. (2014). "Implementasi pendekatan pembelajaran saintifik untuk meningkatkan hasil belajar siswa pada mata pelajaran matematika”. Bandung: UPI

[4]. Natalia. (2016). "Analisis Kesalahan Siswa dalam Mengerjakan Soal-soal pada Materi Operasi Bentuk Aljabar Kelas VIII B SMP Pangudi Luhur 1 Klaten Tahun Ajaran 2015/2016". Yogyakarta: FKIP, USD

[5]. Rahmat Hidayat. (2013). "Hakikat matematika dikenal sebagai ilmu deduktif, ilmu terstruktur dan juga matematika sebagai ratu dan pelayan ilmu."

[6]. Soedjadi. (2000). Kiat Pendidikan Matematika di Indonesia. Bandung: Dirjen Dikti Depdiknas.

[7]. Supatmono. (2009). Matematika Asyik: Asyik Mengajarnya, Asyik Belajarnya. Jakarta : Grasindo.

\section{PROFIL PENULIS UTAMA}

Penulis bernama lengkap "Cindy Aditya Cahyani". Lahir di Kota Salatiga Provinsi Jawa Tengah pada tanggal 08 Mei 1996 dari pasangan Emy Tjahyono dan Dewi Wahyuni. Penulis adalah anak Pertama dari 2 bersaudara. Pendidikan sekolah dasar dimulai dari SDN Gendongan 02 Salatiga pada tahun 2002 - 2008. Setelah itu melanjutkan pendidikan sekolah menengah ke SMPN 2 Salatiga pada tahun 2008 2011 dan terakhir di SMAN 2 Salatiga pada tahun 2011 - 2014. Kemudian penulis melanjutkan studi ke perguruan tinggi di Program Studi Pendidikan Matematika FKIP Universitas Kristen Satya Wacana Salatiga pada tahun 2014. 